\title{
DEVELOPING THE STATUTORY OBLIGATION OF GOOD FAITH IN EMPLOYMENT LAW: WHAT MIGHT HUMAN RESOURCE MANAGEMENT CONTRIBUTE?
}

\author{
Gordon Anderson* and Jane Bryson**
}

\begin{abstract}
The Employment Relations Act 2000 has strengthened individual employee rights in two ways. First, it provides that the parties to an employment relationship must deal with each other in good faith. Secondly, it has made it clear that the standard by which an unjustifiable action is to be judged is an objective one. It is suggested that applying these new provisions will require some realignment of the judicial mindset which has tended to resist interventions into an employer's management of its employees. This article will first discuss the nature and extent of the good faith obligation in the management of the day-to-day individual employment relationship as well as the nature of the changes to the test of justification. It will then go on to consider whether disciplines such as organisational psychology and human resource management good practice provide a potential source of reliable evidence which can contribute to the legal development and re-evaluation of concepts such as good faith and justification. The ability to make such a contribution is dependent on whether the disciplines are sufficiently developed and their principles and practices sufficiently accepted, and also on whether the courts are prepared to accept and give adequate weight to expert evidence that may be adduced.
\end{abstract}

\section{INTRODUCTION}

The genesis of this article lies in the participation of one of the authors as an expert witness in a case concerning the methodology for selecting employees for redundancy. ${ }^{1}$ This experience raised

* Associate Professor, School of Law, Victoria University of Wellington.

** Senior Lecturer, Victoria Management School, Victoria University of Wellington.

1 Jane Bryson gave evidence for the plaintiff in Ross v Wellington Free Ambulance Service Inc [2000] 1 ERNZ 643 (Emp Ct) [Ross]. 
a number of questions for each of the authors given their different academic disciplines (law on the one hand and human resource management ("HRM") and industrial and organisational psychology ("IO psychology") on the other). One of these questions was whether the disciplines of HRM and IO psychology have a potential role to play in assisting the courts to develop appropriate legal standards of employer behaviour. This question seems particularly appropriate at the present time following the enactment of the broad statutory obligation of good faith in the Employment Relations Act 2000 (ERA).

When the Labour Government enacted the ERA it envisaged good faith as both the "oil" of its new approach to employment relations and as playing the central role in the Act's overall objective of building "productive employment relationships through the promotion of mutual trust and confidence."2 In the Explanatory Note to the Employment Relations Bill the Government stated: "The principle of good faith underpins the Bill, both generally and specifically." ${ }^{3}$ The then Minister of Labour has written that the Government saw the re-establishment of co-operative relationships, at the workplace and at industry and national level, as critical to its overall labour market objectives such as reversing low productivity and skill shortages. ${ }^{4}$ While grounded on well-established legal antecedents, the legislative construct of good faith represents an ambitious attempt to develop a comprehensive obligation regulating and changing behaviour across all aspects of employment relationships.

Although less dramatic, the enactment of section $103 \mathrm{~A}^{5}$ is also intended to ensure that a degree of balance is maintained in decisions concerning unjustifiable actions, by requiring that the justification for an action must be "determined on an objective basis" even though the section retains the test of the "reasonable employer" rather than adopting a neutral test. The Employment Court, in the first decision discussing this amendment in detail, has strongly indicated that the new section mandates a wider inquiry than previously and one that more carefully scrutinises an employer's actions. ${ }^{6}$ Clearly there is likely to be a degree of overlap between the need to exercise good faith

2 This comes from the original wording of the object of the Act in section 3, prior to amendment in 2004

3 Employment Relations Bill 2000, (Explanatory Note) 1.

4 M Wilson "The Employment Relations Act: A Framework for a Fairer Way" in E Rasmussen (ed) Employment Relationships: New Zealand's Employment Relations Act (Auckland University Press, Auckland, 2004) 9, 14-18.

5 Section 103A was inserted by section 38 of the Employment Relations Amendment Act 2004. This provision was a response to concerns that the Court of Appeal's judgment in W\&H Newspapers Ltd v Oram [2000] 2 ERNZ 44 (CA) had shifted the test of justification to one that was increasingly responsive to subjective employer judgments. See Mazengarb's Employment Law (loose leaf, LexisNexis, Wellington) vol 1, para ERA103A.3 and following (last updated September 2006).

6 Air New Zealand Ltd v Hudson (30 May 2006) Emp Ct AC 30/06 Judge Shaw. See the extensive discussion at para 89 and following. 
and the need not to make unjustifiable decisions. It is suggested below that good faith in the context of this article is largely concerned with procedural or process good faith and as such is closely related to the need for procedural fairness in making decisions to dismiss. This article will not cover dismissals in detail, but reference will be made to one class of dismissal, redundancy, and the need for fairness in the process of selection and implementation of such dismissals. It might be noted that the need for fairness in such situations has been further reinforced by section 4(1A)(c), which strengthens employee consultation rights in situations where a proposed decision is likely to have an adverse effect on the continuation of an employee's employment.

It should perhaps be stressed that this article is not concerned with the good faith obligation as it relates to collective bargaining and only minimally as it relates to business changes that may impact on employment. Rather it focuses on good faith, and the related concept of justification, in the context of the individual employer-employee relationship ${ }^{7}$ as it impacts on the day to day management of the individual employment relationship. It then goes on to consider whether the judicial development of the obligation in that context can be informed by insights into good practice $^{8}$ in HRM and IO psychology. It is suggested that these two disciplines are the most likely to have the potential to provide a potential source of reliable evidence from which at least some aspects of good faith behaviour can be derived.

\section{THE STATUTORY GOOD FAITH OBLIGATION}

The central role of good faith is set out in the "Key provisions" of the ERA. Section 3, the objects section (as amended in 2004), states that the object of the Act is:

(a) to build productive employment relationships through the promotion of good faith in all aspects of the employment environment and of the employment relationship -

(i) by recognising that employment relationships must be built not only on the implied mutual obligations of trust and confidence but also a legislative requirement for good faith behaviour.

The original object had used the expression "to build productive employment relationships through the promotion of mutual trust and confidence". The amended formulation seems intended to override the interpretation adopted by the Court of Appeal in Coutts Cars Ltd v Baguley, ${ }^{9}$ making

7 See Employment Relations Act 2000, s 4(2) for other employment relationships to which the obligation applies.

8 This article generally uses the term "good practice" rather than "best practice" as the latter has a particular meaning within the HRM literature: see generally J Pfeffer Competitive Advantage Through People: Unleashing the Power of the Workforce (Harvard Business School Press, Boston, 1994).

9 Coutts Cars Ltd v Baguley [2001] 1 ERNZ 660 (CA). Gault J for the majority stated (at para 42) that the new statutory obligation does not introduce "any significantly different obligation to that the courts have placed upon parties to employment contracts over recent years. ... There is no reason why the decisions on 
it clear that Parliament intended a broader and more far reaching obligation than that accepted by the Court. Nevertheless, both the original and amended formulation make it apparent that a major influence in constructing the good faith obligation was the common law implied term of mutual trust and confidence that has been developed, particularly in the United Kingdom, since the 1970s. The emergence of this implied term has been an important development for the contract of employment, recognising as it does a mutuality of obligations in an employment relationship. While the future evolution of this implied term is not fully certain, it is plain that its development by the courts has given much greater weight to the need for fairness and good faith dealing by both parties in employment relationships, but particularly by employers, as employees have always been subject to equivalent obligations by virtue of the implied term of fidelity. By incorporating the common law implied term in the statutory obligation of good faith the ERA gives clear legislative affirmation to the common law developments, while allowing flexibility for further development at common law.

Section 4(1)(a) requires the parties to an employment relationship to "deal with each other in good faith". Originally there was no definition of what constitutes good faith conduct other than paragraph (b), which provides that one party must not do anything that misleads or deceives the other, although the subsection also explicitly provided that paragraph (b) does not limit the general, but undefined, obligation in paragraph (a). Subsection 4(1A), inserted in 2004, now provides that the duty of good faith is "wider in scope than the implied mutual obligations of trust and confidence" and goes on to require the parties to an employment relationship "to be active and constructive in establishing and maintaining a productive employment relationship in which the parties are, among other things, responsive and communicative." This requirement seems intended to partially counter the decision of the Court of Appeal in Auckland City Council v The New Zealand Public Service Association, which was critical of the views of the Employment Court and commented that any "general requirement of 'energetic and positive displaying of good faith behaviour' goes too far."10 While perhaps not going quite as far as the Employment Court, the amendment does make it apparent that good faith involves a positive and proactive approach.

The matters to which the good faith obligation applies are set out in section 4(4), although again it is made plain that these are examples only and not a definitive list. ${ }^{11}$ The list nevertheless includes most matters that are likely to have a significant impact on employees, either collectively or individually. The list includes consultations about "the effect on employees of changes to the employer's business", "proposals that might impact on an employer's employees including proposals to contract out work otherwise done by employees or to sell or transfer all or part of the employer's

Aoraki and New Zealand Fasteners Ltd v Thwaites [2000] 2 NZLR 565 should not continue to provide guidance on the applicable principles."

10 Auckland City Council v The New Zealand Public Service Association [2003] 2 ERNZ 386, para 25 (CA) Gault P for the Court.

11 Employment Relations Act 2000, s 4(5). 
business", and "making employees redundant." The list thus includes most business developments likely to impact on an employee's job security. The 2004 amendment added two new matters to make it clear that good faith applied to bargaining for an individual employment agreement and to "any matter arising under or in relation to an individual employment agreement." 12 While this may have been implicit in the original provision, the amendment leaves no room for ambiguity and reinforces the policy behind the Act that good faith applies to and throughout all employment relationships. As is made clear by sections 3(a)(i) and 4(1A), the obligation is founded on but goes beyond the implied mutual obligations of trust and confidence, a formulation that provides the statutory foundation for requiring observance of the common law obligations centred on the developing obligation of trust and confidence. The statutory obligation thus may well represent a statutory formulation of Freedland's hypothesised overarching principle of a requirement of fair management and performance applicable to all employment contracts. ${ }^{13}$

What then is the likely scope of the obligation? In a case decided under the Employment Contracts Act 1991, Bates v BP Oil Ltd, Judge Colgan distinguished between operational aspects to which the obligation to act fairly and reasonably applied, and "substantive" questions of employment to which it did not. ${ }^{14}$ This distinction would seem to remain valid when considering the statutory good faith obligation, the statutory obligations being confined to how the employment relationship is performed rather than the substance of the underlying terms. Any extension of the obligation to include the substance of the terms of an agreement would conflict with the provisions in the ERA restricting the ability to challenge an employment agreement on the basis that its terms and conditions are unfair. ${ }^{15}$ The Act also specifically restricts the Employment Relations Authority from fixing new terms and conditions of employment, except in very limited circumstances. ${ }^{16}$ The potential impact of the good faith obligation is therefore likely to be limited to constraining the exercise of an employer's discretions and powers, and to constrain the methods by which a decision is made. The importance of such constraints should not, however, be underestimated as they are likely to act as an important check on not only how decisions impacting on employees are made but also on the permissible range of decisions; effectively a requirement of fair management.

12 Employment Relations Act 2000, s 4(4)(bb).

13 M Freedland The Personal Employment Contract (Oxford University Press, Oxford, 2003) 186-188. Freedland sees management and performance as loosely corresponding to the functions of the employer and employee respectively. The principle incorporates the range of implied terms including both fidelity and mutual trust and confidence.

14 Bates v BP Oil Ltd [1996] 1 ERNZ 657, 670 (Emp Ct) Judge Colgan.

15 Employment Relations Act 2000, s 68(4) specifically excludes challenges to an individual employment agreement on the ground that it is unfair or unconscionable, other than a challenge made under section 68 .

16 Employment Relations Act 2000, s 161(2). 
A second initial point concerns the status of the good faith obligation. The ERA states that the parties "must" deal with each other in good faith, ${ }^{17}$ thus imposing a clear statutory obligation which cannot be contracted out of. The good faith obligation incorporates, and extends, the common law implied term of mutual and trust and confidence. In principle, it should strengthen the applicability of that term, particularly in situations where questions might be raised as to the ability of an employer to derogate from the implied term. ${ }^{18}$ In Air New Zealand v Raddock the Court of Appeal held that an express power of dismissal could not be qualified by an implied term of fair dealing. ${ }^{19}$ This conclusion would no longer seem to be sustainable in the context of the ERA, especially given that in that case the employer's motives and good faith appeared highly questionable. ${ }^{20}$

A detailed discussion of the current and developing state of the law of the implied term of trust and confidence is beyond the scope of this article ${ }^{21}$ but it is apparent that evolution of the term ${ }^{22}$ has been the most important common law development affecting the employment relationship over the last three decades. When taken in conjunction with statutory developments, in particular statutory protections against unfair dismissal, the overall effect has been to significantly constrain the unilateral and arbitrary exercise of management prerogative. Brodie argues that the term has developed from two points of origin: a developing private law notion of a requirement of good faith in some forms of contract, and from some aspects of public law - particularly those relating to the legal control over the exercise of certain powers and discretions. ${ }^{23}$ Adopting a position that concurs with the rationale for the statutory formulation of good faith, Brodie argues that mutual trust and confidence is an overarching obligation in employment relationships. He regards this approach as rationalising earlier cases and giving coherence to legal developments in this area. ${ }^{24}$

17 Employment Relations Act 2000, s 238

18 D Brodie "Beyond Exchange: The New Contract of Employment" (1998) 27 ILJ 79, 82 ["Beyond Exchange"]; and Freedland, above n 13, 164-166.

19 Air New Zealand v Raddock [1999] 1 ERNZ 30, 36 (CA) Henry J for the Court.

20 Air New Zealand $v$ Raddock, above n 19, 52-53 Thomas J dissenting. The argument is now academic to some extent as the action for wrongful dismissal has effectively been abolished by section 113 of the ERA, which requires all challenges to a dismissal to be brought as a personal grievance.

21 For an analysis of the current position see Freedland, above n 13, 154-168 and the references therein.

22 The two major cases adopting the term in New Zealand were the Court of Appeal decisions in Auckland Shop Employees Union v Woolworths (NZ) Ltd [1985] 2 NZLR 372 (CA) and Marlborough Harbour Board $v$ Goulden [1985] 2 NZLR 378 (CA).

23 "Beyond Exchange", above n 18, 98; and D Brodie "Mutual Trust and the Values of the Employment Contract" (2001) 30 ILJ 84, 90-91.

24 For a perspective critical of Brodie see D Cabrelli "The Implied Duty of Mutual Trust and Confidence: An Emerging Overarching Principle?" (2005) 34 ILJ 284. 
Also of interest is the position taken by Freedland who, following an analysis of implied terms in general, suggests that all "can be synthesised into an overarching and general principle of contractual fair management and performance" such that the parties to employment contracts "are subject to obligations of management and performance which are fair and reasonable with regard to the nature and provisions of the personal work or employment contract in question and the general normative framework within which it exists." 25

\section{PERSONAL GRIEVANCE LAW}

Before concluding this initial section of the article some features of the law relating to personal grievances should be mentioned. The right to raise a personal grievance, which requires an employer to justify certain actions or decisions, has long acted as a constraint on some aspects of managerial prerogative. This constraint is widely accepted internationally and departs from the common law which allows termination of an employment contract without reasons. A particular feature of New Zealand personal grievance law, however, is that it is not confined to providing a remedy against unjustifiable dismissal but also permits an employee to bring a grievance if their employment is affected to their disadvantage by some unjustifiable action by the employer. ${ }^{26}$ Employees have successfully used this provision to challenge such matters as unjustifiable disciplinary action short of dismissal, denial of access to redundancy provisions, a requirement to use unsafe machinery and demotion or a change in status. In some cases challenges to a nonpromotion have been considered, but the courts have shown a reluctance to become involved in such discretionary matters. Perhaps more importantly in the context of this article, an employee may also raise a personal grievance alleging constructive dismissal or unjustified disadvantage where the employer has failed to take proper steps to protect that employee from intimidation or bullying in the workplace or where the employer has failed to take adequate steps to protect the employee from health and safety risks including work-related stress. Failing to take adequate steps to address such behaviours may also form the basis for an action for breach of contract, often based on the implied term of mutual trust and confidence or failure to maintain a safe workplace. ${ }^{27}$ Such actions will inevitably throw a spotlight on the quality of an employer's HRM practices. Dealing with such issues poses significant practical difficulties if unacceptable behaviours are to be combated and employees protected from their consequences.

25 Freedland, above n 13, 186-187.

26 Employment Relations Act 2000, s 103(1)(b); and see the commentary on this provision in Mazengarb's Employment Law, above n 5, vol 1, paras ERA103.69-ERA103.70.

27 See for example Davis v Portage Licensing Trust (4 May 2006) Emp Ct AC 26/06 Judge Travis; AttorneyGeneral v Gilbert [2002] 1 ERNZ 31 (Emp Ct); and Whelan v Attorney-General [2004] 2 ERNZ 554 (Emp Ct). In Davis v Portage Licensing Trust, above, para 169, it was noted that the court is able to award more generous damages in a contract action than in a personal grievance. See further G Anderson "Reimbursement and Compensation for Unjustified Dismissal" (2006) 12 NZBLQ 230. 


\section{A REALIGNMENT OF THE JUDICIAL MINDSET?}

The combination of the law on personal grievances and the term of mutual trust and confidence has already had the effect of limiting the exercise of employer prerogative and in practical terms has resulted in the need for employers to ensure that they have defensible and robust HRM practices capable of surviving judicial scrutiny where a challenge arises. It has been argued above that in the future the courts will be required to extend this scrutiny, because observance of the general obligation of good faith behaviour requires consideration of the quality of employer processes and in particular HRM and decision making practices as they impact on employees. This will require a shift in the approach of the courts who have traditionally been reluctant to become involved in questioning an employer's commercial decision, other than to ensure that the decision is genuine and that the process involved is fair. In Phipps $v$ NZ Fishing Industry Board the Court commented that: ${ }^{28}$

Employers are entitled to considerable latitude in the management of their employee relations, so long

as they observe the law. What the law requires of them is frequently no more than that their decisions

affecting the livelihood of their employees should stem from reasonably founded beliefs, honestly held.

This approach was clearly supported in the Aoraki Corporation Ltd v McGavin, ${ }^{29}$ and later cases, ${ }^{30}$ where the Court of Appeal stressed managerial rights to make business decisions and clearly expressed the view that employers "have a prima facie right to organise and run its business operation as it sees fit". ${ }^{31}$ This same philosophy seems to have informed a series of unjustifiable dismissal decisions in a series of cases after 1989. In these cases the Court increasingly focussed the test of justification on the range of actions available to a reasonable employer and latterly on those available to the particular employer acting reasonably. It was particularly stressed that a court should not substitute its opinion for that of the employer. ${ }^{32}$

While the courts have on occasions been prepared to require an employer to comply with good management practice, ${ }^{33}$ there is normally a reluctance to impose a general requirement to comply

28 Phipps v NZ Fishing Industry Board [1996] 1 ERNZ 195, 200 (Emp Ct) Goddard CJ.

29 Aoraki Corporation Ltd v McGavin [1998] 3 NZLR 276 (CA).

30 It was supported most notably in New Zealand Fasteners Ltd v Thwaites [2000] 2 NZLR 565 (CA).

31 Aoraki Corporation Ltd v McGavin, above n 29, 294 Richardson P, Gault, Henry, Keith, Blanchard and Tipping JJ.

32 These cases culminated in W\&H Newspapers Ltd v Oram [2000] 2 ERNZ 44 (CA): see Mazengarb's Employment Law, above n 5, vol 1, para ERA103A.6. Section 103A of the ERA was enacted to restore a more neutral test.

33 In Auckland etc Local Authorities Officers' IUWv Mount Albert City Council [1989] 2 NZILR 651 (Emp $\mathrm{Ct}$ ) an employer was held to be in breach of the implied term by failing to provide adequate supervision, training or encouragement in management skills in a situation where the Court regarded these as necessary in carrying out the overall purpose of the contract. 
with good HRM practice. For example, in Anderson v Attorney-General the Court of Appeal held that the implied term of fair treatment does not require an employer to conform at all times to the highest standards of good management practice, commenting that this "would be an unlikely obligation for any employer to accept, and it is certainly not one which could be implied into terms of employment where it is not expressed." ${ }^{34}$ However, the Court did concede that there was "much good sense" in the expert evidence on good practice, while also noting that the awareness of such matters had been much less a decade earlier at the time the complaint arose. ${ }^{35}$

It is argued above that the requirement of good faith requires a re-evaluation of the pre-2000 cases. At a practical level it is now clear both that HRM practice and theory have advanced to a stage where the policies and procedures that constitute good practice are well developed and also that employers should be aware of such practice and should act accordingly. ${ }^{36}$ Supporting the argument that the courts should assert greater control over management practices impacting on employees is that the ERA specifically requires that in building productive employment relationships it is necessary to acknowledge and address the inherent inequality of power in employment relationships. ${ }^{37}$ In NZ Amalgamated Engineers Union Inc v Carter Holt Harvey Ltd the Employment Court, dealing with redundancy consultation, made the point that "[t]his is a case about process and who controls it" and noted the significant advantages an employer possesses through its control of process. ${ }^{38}$ These, it said, "are the practical manifestations of 'the inherent inequality of bargaining power in employment relationships"' referred to in section 3(a)(ii) of the Act. ${ }^{39}$ This argument could equally be applied to employer control of HRM processes. The requirement that the parties be active and constructive in maintaining a good faith relationship also supports a more active judicial review of management practices impacting on employees.

\section{THE CONTRIBUTION OF HRM AND IO PSYCHOLOGY}

If the argument above, that the statutory obligation of good faith requires proactive good management by an employer, is accepted as valid then the question arises as to what constitutes

34 Anderson v Attorney-General (23 October 1992) CA 292/91, 13 (CA) McKay J for the Court. The point has been made that this statement blurs the boundary between the criteria for implying terms in fact and the implication of terms by law: see Mazengarb's Employment Law, above n 5, vol 2, para 1027.

35 Anderson v Attorney-General, above n 34, 13 McKay J for the Court.

36 In Association of University Staff Inc v The Vice-Chancellor of the University of Auckland [2005] 1 ERNZ 224, para 41 (Emp Ct) Judgment of the Court, the Court suggested that professional HRM managers might be expected to be aware of appropriate standards and practice in their field.

37 Employment Relations Act 2000, s 3(a)(iii).

38 New Zealand Amalgamated Engineers Union Inc v Carter Holt Harvey Ltd [2002] 1 ERNZ 597, para 3 (Emp Ct) Colgan J [NZ Amalgamated].

39 NZ Amalgamated, above n 38, para 3 Colgan J. 
good management practice. It is suggested that the disciplines of HRM and IO psychology in particular are not only well placed to provide evidence of such practices but also are likely to provide the best source of evidence as to what constitutes good management of human resources and what are the appropriate procedures for ensuring that proper standards are met. Both HRM and IO psychology are well established disciplines academically. They have also developed a body of considerable applied professional expertise that bridges the gap between academic knowledge and the practical application of such knowledge within the constraints imposed by an organisational environment. While it remains for the courts to determine if a particular course of conduct or a particular decision was made in good faith or is justifiable, that decision is likely to be better informed if expert evidence of good practice is made available to the courts. If, however, the courts are to rely on expert evidence or expert opinion by HRM or IO psychology professionals, then it is necessary that they are not only satisfied of the credentials and of the appropriate professionalism and objectivity of the witness but also that the discipline practised by the witness is sufficiently rigorous and developed to provide reliable evidence upon which the court can base its decision. The remainder of this article, after a brief comment on expert evidence, will discuss whether HRM and IO psychology have reached a stage of development where sufficient confidence can be placed on the evidence of appropriate professional witnesses.

\section{THE USE OF EXPERT WITNESSES}

If the courts are to make use of disciplines such as HRM or IO psychology in developing the obligation of good faith in employment relationships, the necessary information is likely to be obtained through the use of expert witnesses with appropriate skills in the disciplines concerned. Expert witnesses are of course frequently used during the course of litigation and there are no particular problems associated with the use of such witnesses in the employment jurisdiction. Indeed, in the employment jurisdiction both the Employment Relations Authority and the Court have a broad discretion, using their equity and good conscience powers, to admit evidence including that which might be inadmissible elsewhere ${ }^{40}$ Moreover, modern judicial practice permits relatively wide-ranging evidence to be introduced. The Court of Appeal in Attorney-General v Equiticorp Industries has referred to statements by the Federal Court of Australia, in an apparently complicated banking case, to the effect that "it is legitimate for an expert to proffer the kinds of opinions that ... [go] beyond what is good practice to whether or not, in the particular circumstances, what was done was appropriate, imprudent or otherwise open to criticism." 41 The Court indicated that "expert argument as much as expert opinion" is acceptable, particularly in cases involving a judge alone, and even that "it is doubtful that there is now an absolute rule precluding an

40 Employment Relations Act 2000, ss 160(2) and 189(2).

41 Attorney-General v Equiticorp Industries Group Ltd [1995] 2 NZLR 135, 139 (CA) Cooke P for the Court, referring to the judgment of Pincus J in Thannhauser $v$ Westpac Banking Corpn (1991) 104 ALR 485 (FCA). 
expert witness from expressing a view as to the ultimate issue."42 Attorney-General $v$ Equiticorp Industries Ltd was relied on by the Employment Court in Xv Auckland District Health Board. ${ }^{43}$ In that case the Court indicated that experts will generally not be permitted to give evidence about the ultimate issue to be decided; for example, what would a notional fair and reasonable employer have done in particular circumstances? As the Court expressed it: "[W] hat courts generally do not allow is being told, subtly or unsubtly, what some interested or even disinterested person may think should be the outcome based on a sometimes less than comprehensive knowledge of the case." ${ }^{44}$ The Court refused to permit broad opinion evidence by other employers about what they may have done, partly because the issue was a matter for the Court given the test concerned a notional employer, but also for practical reasons relating to the probable inability of witnesses to be fully informed of the case presented. ${ }^{45}$ The Court's decision on the nature of the evidence to be permitted from some other witnesses also provides a good indication of the range of evidence or opinion that may be allowed. In particular, the Court was unwilling to accept what might be best described as advocacy of strong opinion evidence. ${ }^{46}$

This type of evidence, partly because of the strong advocacy flavour, is quite different than that which might be expected from an HRM expert. Such a witness might, for example, be expected to give evidence on matters such as what are generally accepted formulations of an acceptable harassment policy, what is the accepted or best practice associated with dealing with workplace stress, or whether certain psychological tests or evaluation techniques are appropriate or valid in given circumstances. Equally importantly, if such evidence is to be credible, it is likely to be given by persons with appropriate academic and/or professional qualifications and experience, and from an objective and neutral perspective as is feasible. The greater the advocacy and the less the evidence backing the expert, the less credible is their evidence.

\section{A The Ross Decision: An Example of the Use of Expert Evidence}

While expert evidence (for example, on medical issues) is not unusual, there are relatively few cases where the Employment Court has dealt with the more technical aspects of the quality of management practice. One such area, which has arisen on several occasions, has been questions

42 Attorney-General v Equiticorp Industries Group Ltd, above n 41, 139 Cooke P for the Court. See "Employment Law" [2005] NZ Law Rev 577; and New Zealand Law Commission Evidence: Volume 1: Reform of the Law (NZLC R55, Wellington, 1999) paras 71-77, as well as clause 22(1) and (2) of the new Evidence Bill 2005.

43 Xv Auckland District Health Board (31 October 2005) Emp Ct AC52A/05, Judge Colgan.

$44 X v$ Auckland District Health Board, above n 43, para 14 Judge Colgan.

45 Xv Auckland District Health Board, above n 43, paras 23-24 Judge Colgan.

46 See the discussion at $X v$ Auckland District Health Board, above n 43, paras 39-59 Judge Colgan. Although not directly involved in the grievance, the witnesses in question were also not strictly experts but more like advocates for particular groups or points of view. 
relating to the validity of selection criteria for redundancy. In such cases the Court has generally been assiduous in ensuring that selection criteria are notified, not subject to bias and are applied in a consistent and fair manner. Difficulties usually arise in cases where the employer places weight on subjective factors, such as attitude or other imponderables, rather than more objectively measurable factors such as seniority or technical competence. In such cases the Court, although noting the employer's right to make commercial decisions, has undertaken detailed assessments of the criteria used, the surrounding consultation process and the manner in which evaluations were made. For example, in Apiata v Telecom New Zealand Ltd the Court held a dismissal unjustified where there was a "subjective assessment of an employee's attributes behind closed doors without an opportunity for the employee to comment on those subjective assessments." 47 In Murfitt v Centrepoint Ltd a selection process was held to be unfair because in essence it made false comparisons between employees and gave the impression that the position in question required greater skills than actually needed. ${ }^{48}$ The Court also noted that the evidence suggested that the person was targeted rather than the position. ${ }^{49}$ However, in both Unilever Ltd $v$ McDonald ${ }^{50}$ and Dunn v Methanex ${ }^{51}$ the Court supported assessment methodologies where there was clear evidence that steps had been taken to minimise potential bias. In the first of these cases there had been consultation with both employees and their union on the methodology. It is not, however, fully apparent from these decisions whether or not expert evidence was lead on the methodology and process used.

One case where there was such evidence, and also a conflict between the witnesses over the appropriate methodology and process for selecting employees for redundancy, was Ross $v$ Wellington Free Ambulance Service Inc. ${ }^{52}$ It is worth considering the case in a little more detail. The employer decided to select staff on the basis of a comparative competency evaluation developed for the employer by professional HRM consultants. The selection criteria were based on five identified key competencies, including attitude and clinical skills. The weighting for each competency varied but greatest weight was accorded to the more subjective such as "attitude", and the least to professional competencies such as "clinical skill." Each ambulance officer was ranked by a management team, as well as the respective shift team leaders. The management evaluation was given a weighting of $8 / 9$ and that of the shift leaders $1 / 9.53$ The plaintiff alleged that his negative evaluation was a result of extraneous considerations, and in particular that his

47 Apiata v Telecom New Zealand Ltd [1998] 2 ERNZ 130, 137 (Emp Ct) Judge Finnigan.

48 Murfitt v Centrepoint Ltd [1999] 2 ERNZ 955 (Emp Ct).

Murfitt $v$ Centrepoint Ltd, above n 48, 967 Judge Shaw.

50 Unilever Ltd v McDonald [2001] ERNZ 804 (Emp Ct).

51 Dunn v Methanex [1996] 2 ERNZ 222 (Emp Ct).

52 Ross, above n 1.

53 The relevant document including weightings is set out at Ross, above n 1, 655 Judge Shaw. 
outspokenness on management issues had wrongly prejudiced his competency evaluation. This evaluation seemed to be accurate and the Court specifically made reference to differing perceptions, in particular management's, of the plaintiff's criticisms as "negative and disruptive." 54

Both parties called expert witnesses to assess the selection methodology. As might be anticipated, the two witnesses took quite different views. ${ }^{55}$ While there were a number of detailed criticisms of both the methodology and the process, the critical points related to the heavy weighting given to management assessment, the balance of weightings between job competence skills and more intangible factors such as attitude, and the fact that while team leaders assessed employees individually the management assessment was carried out as a group. ${ }^{56}$ The plaintiff's expert's criticism was essentially that each member of the management team should have completed an individual score sheet, that the weightings given to various competencies were not appropriate and unbalanced, and that the weighting (or importance) of the team leaders' assessment compared with that of the management team was low. She took the view that, given the close contact between team leaders and ambulance officers, their assessment should have been given at least equal weight as that of the management group. The defendant's expert on the other hand was more sanguine about the process, considering it "reasoned and supportable" and suggesting that the plaintiff's expert did not recognise the "practical realities" of the assessment process. She concluded: "Overall, if those involved in the process were comfortable with the weightings applied, as qualified people, I see no reason to question their judgement." 57 One point that emerges from the evidence, and which is relevant to the discussion below, is the different approaches taken towards the evaluation instrument. The plaintiff's evidence tended to provide a more technical appraisal, while that of the defendant's focussed much more on the management of the particular situation and how management dealt with the evaluation. This division reflects the difference between IO psychology and HRM discussed below.

Given this conflict the Court appears to have elected to refuse to deal with it, taking the view that the gap between the witnesses was "more apparent than real". More worrying, however, was the rationale for upholding the employer's methodology. The Court found that it was "not irrational" and "Dr Bryson was unable to convince the Court that the assessment and its results had no validity at all." ${ }^{15}$ The Court did add that it took the view that the criteria were consistently applied and there were objective reasons for the conclusions reached. With respect, however, this finding failed to

54 Ross, above n 1, 658 Judge Shaw.

55 The evidence is summarised in Ross, above n 1, 656-657 Judge Shaw.

56 Given that there were clear differences between managers and shift leaders on attitude, the weightings effectively heavily favoured management opinion.

57 Ross, above n 1, 657.

58 Ross, above n 1, 658 Judge Shaw. 
address the core question of the validity of the underlying methodology, and in particular the clear impression that it was constructed to get rid of employees disliked by management. The Court, by requiring the plaintiff to demonstrate that the methodology had no validity at all, set an almost insurmountable barrier for the plaintiff. Moreover, the standard adopted effectively rendered any detailed evaluation of the expert evidence unnecessary. It should be noted, however, that the case was decided at a time when the Court of Appeal had strongly discouraged questioning employer decisions and that factor may well have been behind the unwillingness to question what appeared to be a seriously flawed methodology.

One lesson that emerges from the Ross case is that if expert evidence is to play a positive role then it is important that the nature and production of the evidence be managed so that it is clear to both the court and experts what the critical questions are and also what the benchmark standard is which will be used to evaluate the evidence. In Ross the standard set was such that the plaintiff's expert faced a very high barrier, but equally importantly, one that was not clear during the hearing. It is suggested that given the changes to the law since the Ross decision, the quality of employer practices must be given greater scrutiny. Practices, be they evaluation methodologies, dispute handling procedures or workplace monitoring and associated procedures to recognise and to deal with bullying, stress and the like, should be subject to evaluation by the courts against the benchmarks of good practice. HRM and IO psychology are the two disciplines that are likely to be best placed to provide evidence on such a benchmark, but the contribution they might make will depend on the maturity of each discipline.

\section{HRM, IO PSYCHOLOGY AND DETERMINING GOOD PRACTICE}

HRM is a discipline of around two decades standing, taught widely in Anglo-American tertiary institutions. It is essentially an extension of the management discipline, occasionally with an employment relations or industrial relations perspective included. HRM is an application of management in a particular sphere of activity - managing people - and HRM practitioners (both inhouse and external consultants) are first and foremost agents of management and the organisation. Kochan notes a global crisis of trust in HRM practitioners, brought about by perceived inequities, unfair practices and lack of job security in organisations for which they are seen to be responsible. ${ }^{59}$ This presents a challenge not only for HRM practitioners but also for the academic discipline, its research focus and ability to inform good practice.

The HRM literature acknowledges that there are a variety of HRM strategies and thus policies and procedures that can be adopted by an organisation. Choice of strategy is commonly held to depend upon a range of contextual factors, such as general business strategy, size of business, type

59 T Kochan "Contemporary IR/HR Challenges: Global Perspectives" (Special seminar to the Industrial Relations Society of Queensland, Department of Industrial Relations of the Queensland Government and Griffith University, Australia, November 2003). 
of business, nature of the work, the state of the labour market and so on. Much of the debate in the HRM literature is at the level of strategy. Many studies tend to be generic, focusing on bundles of HRM practices rather than specific practices, ${ }^{60}$ which render them rather unhelpful for the practitioner seeking guidance on the detail or efficacy of an actual practice. Gibb argues that this is largely due to the fact that most research on HRM practices only canvasses the opinions of managers (and often only human resource managers) and not those of employees (or line managers) in the workplace. ${ }^{61}$ Hence such research may only capture the strategic intent of HRM practices rather than their practical implementation and impact. Some studies now include employee and other viewpoints. ${ }^{62}$ To date, HRM practice research has been unfortunately selective in its samples, focusing on the successful or popular organisations, seeking mainly management opinion, and as a result reporting only on strategic intent and not the specific implementation practices of HRM.

This selectivity contributes to problems of reliability and validity of measurement and hence limits the generalisability of results. Von Glinow and others studied ten countries in search of international HRM practice. ${ }^{63}$ They highlighted the difficulty of generalisability of HRM practice from country to country. Yet the universal marketing of HRM textbooks and research assumes generalisability across countries and across organisations. Management in general has been plagued by a "one size fits all" approach and isomorphic organisational tendencies encouraged by trenddriven consulting practices and, in Australasia, a small pool of management talent. Hence, paradoxically, there is a drive towards similarity in bundles of practice across organisations, but a lack of generalisability of research results. For instance, one of the best known international surveys of HRM practice which extends to Australia and New Zealand, the Cranfield survey, tends to report only on bundles of practice. Kramar, reporting the results of the Cranfield survey in Australia, indicates (similar to other countries) a reliance on compulsory redundancies for downsizing but tells us nothing of the actual practices in implementing this. ${ }^{64}$ Similarly, Johnson, reporting the New Zealand survey results, laments the limited application of best practice HRM in New Zealand organisations. ${ }^{65}$ Interestingly, although he never articulates best practice, he is clearly comparing the

60 J Purcell "Best Practice and Best Fit: Chimera or Cul-de-sac" (1999) 9(3) HRM J 26.

61 S Gibb "The State of Human Resource Management: evidence from Employees' Views of HRM Systems and Staff" (2001) 23(4) Employee Relations LJ 318.

62 Gibb, above n 61; D Grant and J Shields "In Search of the Subject: Researching Employee Reactions to Human Resource Management" (2002) 44 Journal of Industrial Relations 313; D Guest "Human Resource Management - the Worker's Verdict" (1999) 9 HRM J 5.

63 M Von Glinow, E Drost, M Teagarden "Converging on HRM Best Practices: Lessons Learned from a Globally Distributed Consortium on Theory and Practice" (2002) 40 Asia Pacific J of HR 146.

64 R Kramar Cranfield-Price Waterhouse Coopers Survey on International Strategic Human Resource Management (Macquarie Graduate School of Management, Macquarie University, 2000).

65 E Johnson "The Practice of Human Resource Management in New Zealand: Strategic and Best Practice?" (2000) 38 Asia Pacific J of HR 83. 
survey results to some standard in each HRM practice bundle. He makes five suggestions why employers do not follow best practice: 1) they are uninformed/ignorant of best practice; 2) HRM practitioners disbelieve or disparage best practice; 3) best practice appears impractical and costly, particularly for small organisations; 4) HRM practitioners have insufficient clout to sell their ideas to the organisation; and 5) it is expedient not to follow best practice. ${ }^{66}$ Whichever reason, or combination of them, explains the result it illustrates a disturbing disconnection between research and practice. This phenomenon is not peculiar to New Zealand; lack of uptake of so-called HRM best practice is reported around the globe. ${ }^{67}$

It is no wonder, therefore, that a recent article criticises the use of HRM expert witnesses in employment litigation cases in the United States. ${ }^{68}$ Rogers contends that HRM experts are unable to provide useful evidence because there is no accepted minimum standard of practice in HRM, nor an accepted research method, and that so-called HRM experts and practitioners have no common training, educational experience or professional regulation. As a result, she maintains that HRM expert testimony tends to be merely assertion unaccompanied by evidence or research. It would seem there is plenty of pressure for HRM research to become more relevant, accessible and authoritative if it is to be regarded as factually credible. HRM academics need to improve their ability to conduct reliable and valid research into the specific practices and tools that underpin the generic bundles of practice.

This is where the literature of IO psychology is particularly instructive and helpful to HRM. IO psychology is a well established discipline, with a longer and more impressive research history than that of HRM. IO psychology comes from a science-oriented positivistic research tradition and thus has tended to more of a measurement and evaluation focus on specific practices or processes. Above all it demonstrates a particular concern with the validity, reliability, utility and overall effectiveness of a broad range of HRM or organisational practices. The focus of IO psychology interest, as outlined by the New Zealand Psychological Society, is: human-machine interaction and workplace design; job analysis; personnel selection and assessment; counselling, personal and career development; training; employee relations and motivation; organisational development and change. ${ }^{69}$ Within these practice areas there is a well established body of evidential research literature which can be drawn upon. ${ }^{70}$ For instance, IO psychology provides extensive evaluation,

66 Johnson, above n 65,81 .

67 Purcell, above n 60, 27.

68 A Rogers "Human Resources 'Expert' Testimony in Employment Litigation" (2000) 28 Employee Relations LJ 29.

69 New Zealand Psychological Society "Industrial and Organisational Psychology: Division Site" < www.psychology.org.nz/industrial> (last accessed 27 October 2006).

70 For examples refer to Gerard P Hodgkinson and J Kevin Ford (eds) International Review of Industrial and Organizational Psychology (Wiley Chichester), which has been published annually since 1986. 
statistical analysis and critique of the full range of personnel selection practices from job analysis techniques through interview methods, specific psychometric tests, and reference checking to assessment centre processes. Similarly, the proliferation of competency assessment frameworks and instruments used in organisations have remained largely unchallenged by the HRM academic community, the main challenges coming from those with training in IO psychology. ${ }^{71}$ Globally, IO psychologists draw on largely similar education at tertiary level and on a commonly accepted set of research methods, albeit that these are always open to debate as is the case in any self-critical discipline. The practice of the profession of psychology is regulated and IO psychology is a particular area of professional competence. ${ }^{72}$

So, to what extent can HRM or IO psychology potentially be used as a bolster for good faith conduct? There is scope for an important contribution by HRM but this is reliant on ongoing improvement in the practice literature. Even if practice research has been flawed or too generic, it still remains the case that there are better and worse ways of doing things in HRM - and the better ways hinge around improving the reliability and validity of measurement, focusing not only on bundles but also on detailed practice and process, and underpinning all actions with a clarity of moral reasoning and principle. However, in the present state of the disciplines, IO psychology is much more likely to provide the research evidence base and professional credibility required of an expert witness in the area of organisation practice in the management of people.

\section{CONCLUSION}

This article suggests that HRM and organisational psychology have a potential role to play in assisting the law to develop standards of employer fairness and good faith conduct. The ability of these disciplines to contribute is, however, limited by two factors. The first is the receptiveness of the law to such expert testimony. Generally the courts are more likely to be responsive to technical expert evidence or evidence based on sound empirical research rather than "opinion" evidence. ${ }^{73}$ Equally, in spite of Ross, one might expect technical criticism or evaluation relating to selection and competency instruments to be accepted. Greater acceptance of such evidence is, however, highly dependent on the standard used to assess employer conduct. Until 2000 New Zealand law was extremely favourable to employers, allowing them very wide latitude and discretion so that the room for expert, or indeed any, challenges was limited. Given the move to a more objective and balanced test of justifiable conduct and the positive underlying obligation of good faith there should clearly

71 J Shippmann and others "The Practice of Competency Modelling" (2000) 53 Personnel Psychology 703.

72 In New Zealand IO psychology has not yet claimed a separate scope of practice category under the Health Practitioners Competency Assurance Act 2003; it is within the general psychology scope.

73 For example, in Aoraki Corporation Ltd v McGavin, above n 29, the Court of Appeal had little difficulty in accepting statistical evidence from the Victoria University of Wellington collective bargaining database. 
be more room for expert input from HRM or IO psychology to assist in determining the types of conduct that may or may not constitute good faith and fair dealing within an organisation.

The second factor is the extent to which the disciplines of HRM or IO psychology are sufficiently developed to provide convincing and credible evidence for a court. Currently the state of development is uneven, but on the other hand the degree of development might be expected to be greatest where evidence might be useful - that is in relation to the technical aspects of the validity of assessment instruments and the like. HRM and IO psychology are important disciplines in the management of human resources and have a direct impact on employees then. If these techniques are used in a way that is questionable, unethical, inappropriate or biased then employees will suffer an unjustified detriment. If they are to challenge such detrimental action, legal counsel and disciplinary experts must be able to convince the courts of the validity of the challenge to the employer actions - a task that requires the disciplines to work together. 